\title{
Antibodies to human papillomavirus type 16 E7 related to clinicopathological data in patients with cervical carcinoma
}

Department of Dermatovenereology, Erasmus University Rotterdam, Rotterdam, The

Netherlands M F D Baay E Stolz

University Hospital Groningen, Groningen, The Netherlands: Department of Obstetrics and Gynaecology J M Duk M P M Burger $\mathrm{H}$ W A de Bruijn Institute for General Practice K H Groenier

Department of Pathology, Section of Molecular Pathology, Free University of Amsterdam, Amsterdam, The Netherlands J Walboomers

Department of Virology, Section of Fundamental Virology, University of

Amsterdam,

Amsterdam, The

Netherlands

$\mathrm{J}$ ter Schegget

Department of Immunology and Infectious Diseases, Diagnostic Centre SSDZ,

Delft,

The Netherlands

P Herbrink

Correspondence to: Dr P Herbrink, Department of Immunology and Infectious Diseases, Diagnostic Centre SSDZ PO Box 5010, 2600 GA Delft, The Netherlands.

Accepted for publication 13 October 1994

\begin{abstract}
Aims-To investigate the correlation between antibodies to the transforming protein E7 of human papillomavirus (HPV) type 16 and clinicopathological indices in women with cervical squamous carcinoma.
\end{abstract}

Methods-A synthetic peptide of the HPV type 16 E7 protein (amino acids 6 to 35) was used to screen sera from 29 children, 130 women with cervical intraepithelial neoplasia, 443 women with cervical cancer, and 222 controls, for antibodies against this viral antigen. $\mathrm{Bi}$ variate and multivariate analyses were used to investigate the correlation between the serological status in the pretreatment sera and clinicopathological indices (size of the lesion, histological grade, stromal infiltration, vascular invasion, and nodal spread). Survival analysis was done using the Cox regression model for all FIGO stages and stages IB and IIA.

Results-Cervical carcinoma patients had a significantly higher prevalence of antibodies to synthetic peptide E7/6-35 than women with cervical intraepithelial neoplasia $(17.7 \% v 7 \%, p<0.005)$ or controls $(17.7 \% v 11 \%, p<0 \cdot 05)$. Bivariate analysis of the data on the presence of antiE716-35 antibodies in the pretreatment sera from these patients and clinicopathological indices showed a significant correlation between the presence of antiE7 16-35 antibodies and the size of the lesion $(p=0 \cdot 0009)$, histological grade $(p=$ $0.031)$, and lymph node metastasis $(p=$ 0.011). In addition, the Cox regression model, analysing four risk factors which can be determined before treatment, showed a significant correlation between the presence of anti-E7 $16-35$ antibodies and a worse prognosis $(p=0 \cdot 003)$. Survival analysis revealed that both for all FIGO stages $(p=0.0005)$ and for stages IB and IIA alone $(p=0.0021)$, antiE7/6-35 positive patients before treatment had a significantly shorter life expectancy.

Conclusions-The presence of antibodies against E7/6-35 in pretreatment sera from patients with cervical carcinoma correlates with the size of the lesion, lymph node involvement, and a worse prognosis.

(f Clin Pathol 1995;48:410-414)

Keywords: Human papillomavirus, cervical cancer, antibody response.

Human papillomaviruses (HPV) are a group of viruses which are associated with various proliferative diseases in the infected epithelium. ${ }^{1}$ To date, more than $70 \mathrm{HPV}$ types have been reported. Some of these, among which HPV types 6,11,16, and 18 are the most common, are associated with lesions in the anogenital tract. ${ }^{2}$ The "benign" types 6 and 11 are mainly associated with condylomata acuminata. Of the oncogenic HPV types, HPV16 is most frequently found in cervical carcinomas and the viral genome is often found integrated into the cellular genome. ${ }^{3}$ The nuclear protein E7 of HPV-16 is considered to be one of the two major proteins involved in malignant transformation and the maintenance of the transformed phenotype of cells. The viral oncoprotein E7 is consistently transcribed in both HPV positive cervical cancer cell lines and cervical cancers. ${ }^{45}$

Until recently, few data were available on the humoral immune response to HPV-16. Jochmus-Kudielka et al ${ }^{t}$ have reported a 14 fold higher prevalence of antibodies to HPV$16 \mathrm{E} 7$ in sera from cervical carcinoma patients than in age and sex matched controls, when fusion proteins were used in western blotting assays for the screening of sera for the presence of HPV antigen specific antibodies. Using synthetic peptides with known B cell epitopes, ${ }^{7-9}$ similar results have been obtained to those found with western blotting by Jochmus- Kudielka et al. ${ }^{6}$

To date, no data have been published concerning the prevalence of antibodies against HPV-16 E7 in sera from patients with cervical squamous cell carcinoma in relation to tumour indices, such as lesion size and nodal spread, or to survival. To investigate the possible correlation between the presence of antibodies against HPV-16 E7 and tumour indices, pretreatment sera from cervical carcinoma patients were tested in an enzyme linked immunosorbent assay (ELISA) using a synthetic peptide. This peptide was chosen to represent reported major B cell epitopes of HPV-16 E7 
(aa $2-21,{ }^{10}$ aa $1-20$ and aa $10-30,{ }^{7}$ aa $10-15,{ }^{11}$ aa $10-14,{ }^{12}$ and aa $10-20^{13}$ ).

Using bivariate and logistic regression analysis the results obtained for these cervical cancer patients were correlated with the size of the lesion, histological grade, stromal infiltration, vascular invasion, and nodal spread. In addition, anti-E7 positivity was related to survival.

\section{Methods}

SERA

The age distribution of patient and control groups is shown in table 1 . Twenty nine sera of children between 0.5 and 9 years of age were used to determine the cut off value. One hundred and thirty sera from women with different grades of cervical intraepithelial neoplasia (CIN) and 51 sera from patients with squamous cell cervical carcinoma were obtained from the Department of Gynaecology, University of Amsterdam (head: Prof Dr F B Lammes). A further 392 pretreatment sera from women with squamous cell cervical carcinoma were obtained from the Department of Obstetrics and Gynaecology, University Hospital Groningen. The control group consisted of 222 healthy women with a similar age distribution. No data on HPV DNA typing were available. All women in the Amsterdam control group had normal cytology and were matched to the cancer patient group for age, sex, and socioeconomic status. The control group for cervical cancer patients from Groningen consisted of sera sent in for routine screening for other infectious diseases. No data on cytology were available from the Groningen control group.

\section{CLINICOPATHOLOGICAL INDICES IN PATIENTS} WITH CERVICAL CARCINOMA

The staging of the 443 patients with cervical carcinoma was in accordance with the recommendations of the International Federation of Gynaecology and Obstetrics (FIGO). Clinicopathological data other than stage were only available from 300 patients treated in Groningen. Patients from whom blood samples had been drawn after exconisation were excluded from the analysis. Examination of the patients was performed under general anaesthesia. During this procedure, the lesion size (largest diameter) was estimated routinely and expressed in centimetres for the large majority of patients.

Table 1 Age distribution of patient and control groups

\begin{tabular}{lrc}
\hline & \multicolumn{3}{c}{$\begin{array}{l}\text { Mean age (SD) } \\
\text { (years) }\end{array}$} \\
\hline Children & 29 & $3.6(2 \cdot 5)$ \\
CIN 1-3 & 130 & $32.5(7 \cdot 9)$ \\
SCC & 443 & $50 \cdot 9(15 \cdot 7)$ \\
SCC Amsterdam & 51 & $52 \cdot 5(13 \cdot 0)$ \\
SCC Groningen & 392 & $50 \cdot 7(16 \cdot 0)$ \\
All controls & 222 & $50 \cdot 2(16.3)$ \\
Controls Amsterdam & 59 & $51 \cdot 2(12 \cdot 8)$ \\
Controls Groningen & 163 & $49 \cdot 3(17 \cdot 7)$ \\
\hline
\end{tabular}

$\mathrm{CIN}=$ cervical intraepithelial neoplasia; $\mathrm{SCC}=$ squamous cell carcinoma.
Patients with stage IB or IIA were mainly treated by preoperative intracavitary radiotherapy, followed by radical hysterectomy with bilateral salpingo-oophorectomy and pelvic lymphadenectomy four weeks later. Postoperative whole pelvis radiotherapy was applied if lymph node metastases or positive resection margins, or both, were present. Patients with stage IIB and most of the patients with stage III were treated by radiotherapy only, if possible followed by adjunctive hysterectomy. In the remaining stage III patients and in all stage IV patients, treatment was individualised using combinations of radiotherapy, surgery, and chemotherapy.

To correlate anti-E7 positivity with the histopathological data in bivariate analysis, all the available biopsy or cone material of 300 patients was carefully reviewed. Tumours were classified into well differentiated (grade 1), moderately differentiated (grade 2), poorly differentiated (grade 3), or undifferentiated (grade 4) squamous cell carcinoma, in accordance with the criteria laid down by Ferenczy and Winkler. ${ }^{14}$

Criteria for the assessment of the clinical course of the disease were described previously. ${ }^{15}$ Briefly, "complete remission" (no evidence of disease) was defined as the absence of all tumour lesions three months after completion of treatment or during follow up. "Residual disease" existed when tumour lesions were still known to be present after treatment. "Progression of disease" was defined as the appearance of new lesions, the growth of a pelvic mass or other known tumour lesions, or a distinct deterioration in the clinical status of a patient with a known tumour ultimately resulting in death. "Recurrent disease" was used to indicate the reappearance of disease in patients who experienced complete remission. "Poor prognosis" is used to indicate the risk for residual, progressive, or recurrent disease. From 367 patients with cervical carcinoma, consecutively admitted and treated at the department of Gynaecological Oncology in Groningen, follow up data were available. Of these 367 patients, 106 died of cancer.

\section{SYNTHETIC PEPTIDE}

The synthetic peptide, encompassing amino acids 6-35 (PTLHEYMLDLQPETTDLYCYEQLNDSSEEE) of the HPV-16 E7 ORF, was purchased from the Department of Immunology and Medical Microbiology, TNO Medical Biological Laboratory, Rijswijk, The Netherlands. The peptide was synthesised by solid phase synthesis according to Merrifield ${ }^{16}$ on polystyrene resin ( $1 \%$ cross linking), using an automated peptide synthesiser (SAM-2, Biosearch). Synthetic peptides were purified by chromatography on Sephadex G-15 and reverse phase high performance liquid chromatography (HPLC).

ELISA

Synthetic peptide $(100 \mu \mathrm{l}$ per well at $5 \mu \mathrm{g} / \mathrm{ml}$ in phosphate buffered saline (PBS), $\mathrm{pH} \mathrm{7.2)}$ 
was coated onto 96-well Maxisorp plates (Nunc) for one hour at $37^{\circ} \mathrm{C}$. Control wells were treated in a similar way, with the omission of synthetic peptide from the buffer. After six rinses with distilled water the plates were blocked with $1 \%$ gelatin in PBST (PBS containing $0.05 \%$ Tween 20 ) for one hour at $37^{\circ} \mathrm{C}$. Sera were incubated in a 1:100 dilution in PBST $+1 \%$ gelatin for one hour at $37^{\circ} \mathrm{C}$. Goat anti-human IgG peroxidase (1:6700 in PBST, $1 \%$ gelatin, Diagnostic Centre SSDZ) was used as a conjugate. After one hour at $37^{\circ} \mathrm{C}$ the plates were washed six times (PBST), after which substrate was added $\left(3,3^{\prime}, 5,5^{\prime}\right.$-tetramethyl-bendizine, Aldrich Chemie). After $20 \mathrm{~min}$ the reaction was stopped with $2 \mathrm{~N}$ $\mathrm{H}_{2} \mathrm{SO}_{4}$ and colour development read with a Titertek Plate reader at $450 \mathrm{~nm}$.

Each sample was tested in at least three independent experiments. Sera which were eventually scored as equivocal were tested in at least five independent experiments. In each experiment all sera were tested in duplicate on peptide coated wells and control wells, and the mean reactivity of the control wells was subtracted from the mean reactivity of the coated wells. A cut off value was determined from the children's sera using the mean absorption +3 times the standard deviation as described by Krchnak et al. ${ }^{7}$ For intratest comparison, positive, negative, and borderline positive sera were included in each plate. For intertest comparison, optical densities were recalculated into ratios by division by the cut off value. Using the cut off values, none of the children's sera was found positive for antibodies against synthetic peptide E7\6-35.

\section{STATISTICAL METHODS}

The relationship between clinical stage of the tumour and the presence of anti-HPV-16 E7 antibodies was calculated using the Pearson $\chi^{2}$ test to compare the frequency of the presence of antibodies between 2 or $>2$ groups. The interrelationships between anti-E7 $\backslash 6-35$ positivity in pretreatment sera from cervical carcinoma patients and tumour related variables were investigated using bivariate and logistic regression analysis. The prognostic value of anti-E7 $\backslash 6-35$ and other possible risk factors was determined in the Cox regression model. The data used for bivariate and logistic regression analysis of the Groningen patient group included stage of disease (FIGO stage), lesion size, tumour grade, lymph node status, vascular invasion, depth of infiltration, and presence of antibodies against E7 synthetic

Table 2 Prevalence of antibodies against HPV-16 E入 6-35 in sera from patients with cervical intraepithelial neoplasia (CIN), cervical cancer, and controls

\begin{tabular}{llrrl}
\hline & \multicolumn{4}{c}{ Anti-E\6-35 positive } \\
\cline { 2 - 5 } & $N$ & $n$ & $\%$ & \multicolumn{1}{c}{ Mean ratio } \\
& $N$ & \multicolumn{1}{c}{$n$} & \multicolumn{1}{c}{ (SD) } \\
\hline CIN & 129 & $9 \dagger$ & 7.0 & $0.32(0.82)$ \\
Cervical carcinoma & 424 & 75 & 17.7 & $0.61(1.11)$ \\
Controls & 218 & $24^{*}$ & 11.0 & $0.40(1.02)$ \\
\hline
\end{tabular}

${ }^{*} \mathrm{p}<0.05,+\mathrm{p}<0.005 v$ cervical carcinoma patients.
Table 3 Prevalence of antibodies against HPV-16 E7 6-35 in sera from 424 patients according to the stage of disease

\begin{tabular}{llll}
\hline & & \multicolumn{2}{c}{ Anti-E\6-35 positive } \\
\cline { 3 - 4 } FIGO stage & $N$ & $n$ & $\%$ \\
\hline IB & 203 & 30 & $14 \cdot 6$ \\
II & 163 & 30 & $18 \cdot 4$ \\
III & 39 & 5 & $12 \cdot 8$ \\
IV & 19 & 10 & $52 \cdot 6$ \\
\hline
\end{tabular}

peptide 6-35. Differences bètween survival curves were computed by means of the log rank test.

\section{Results}

PREVALENCE OF ANTI-E7\6-35 ANTIBODIES IN

PATIENT GROUPS AND CONTROLS

The seroreactivity of the different groups to synthetic peptide E7\6-35 is shown in table 2. Twenty four sera, 19 from patients with cervical carcinoma, one from a CIN patient, and four from controls matched to the cervical carcinoma patients, did not give consistent results on repeated testing. These sera, which gave both low positive and high negative results, were scored as equivocal and excluded from statistical analyses.

With peptide E7 $\backslash 6-35$, seroreactivity was significantly higher in patients with invasive carcinoma than in the group of matched controls $(p<0.05)$, or women with CIN $(p<0.005)$. No significant differences were found for seroreactivity against peptide E7 $\backslash 6-35$ between patients with different grades of $\mathrm{CIN}$ (CIN 1-3; data not shown).

PREVALENCE OF ANTI-E7\6-35 ANTIBODIES IN DIFFERENT FIGO STAGES

Prevalence rates of antibodies against peptide E7 $\backslash 6-35$ in the different FIGO stages of patients with invasive carcinoma are shown in table 3. When seroreactivity against peptide E7 $\backslash 6-35$ was compared between the four FIGO stages, a statistically significant trend of increasing seropositivity with increasing stage was obtained $\left(\chi^{2}=6.38 ; \mathrm{df}=1 ; \mathrm{p}=0.01\right)$. Analysis

Table 4 Pretreatment sera from 300 patients with cervical carcinoma: bivariate correlation of anti-E $\backslash 6-35$ positivity with clinicopathological tumour indices

\begin{tabular}{|c|c|c|c|}
\hline & \multicolumn{2}{|c|}{ Anti-E $\backslash 6-35$ pos } & \multirow[b]{2}{*}{$p^{a}$} \\
\hline & $\begin{array}{l}\text { n/total } \\
\text { evaluable }\end{array}$ & $\%$ & \\
\hline $\begin{array}{l}\text { Lesion size } \\
\quad<4 \mathrm{~cm} \\
\quad \geq 4 \mathrm{~cm}\end{array}$ & $\begin{array}{l}14 / 116 \\
40 / 132\end{array}$ & $\begin{array}{l}12 \cdot 1 \\
30 \cdot 3\end{array}$ & 0.0009 \\
\hline $\begin{array}{c}\text { Differentiat } \\
1,2 \\
3,4\end{array}$ & $\begin{array}{l}35 / 213 \\
24 / 71\end{array}$ & $\begin{array}{l}16 \cdot 4 \\
33 \cdot 8\end{array}$ & 0.031 \\
\hline $\begin{array}{c}\text { Depth of st } \\
\leq 5 \mathrm{~mm} \\
>5 \mathrm{~mm}\end{array}$ & $\begin{array}{l}\text { on } \\
6 / 32 \\
22 / 87\end{array}$ & $\begin{array}{l}18 \cdot 8 \\
25 \cdot 3\end{array}$ & NS \\
\hline $\begin{array}{c}\text { Vascular inv } \\
\text { Negative } \\
\text { Positive }\end{array}$ & $\begin{array}{l}30 / 177 \\
24 / 83\end{array}$ & $\begin{array}{l}16 \cdot 9 \\
28 \cdot 9\end{array}$ & 0.04 \\
\hline $\begin{array}{c}\text { Lymph nod } \\
\text { Negative } \\
\text { Positive }\end{array}$ & $\begin{array}{l}22 / 139 \\
16 / 46\end{array}$ & $\begin{array}{l}15 \cdot 8 \\
34 \cdot 8\end{array}$ & 0.011 \\
\hline
\end{tabular}


of the IgG content in the patients' sera did not show a statistically significant difference between the different FIGO stages.

CORRELATION OF ANTI-E7/6-35 IN PRETREATMENT SERA FROM PATIENTS WITH CERVICAL CARCINOMA WITH CLINICOPATHOLOGICAL INDICES

We examined whether tumour associated factors are related to the E7\6-35 serum levels. The results are shown in table 4 . Before treatment patients with a lesion size $\geq 4 \mathrm{~cm}$ had a significantly higher prevalence of antibodies against E7 $\backslash 6-35$ than patients with a lesion size $<4 \mathrm{~cm}(\mathrm{p}=0.0009)$. In addition, patients with poorly or undifferentiated carcinoma or with lymph node metastases showed a significantly higher prevalence rate of antibodies against E7 $\backslash 6-35$ compared to patients with well or moderately differentiated squamous cell carcinoma $(p=0.031)$ or without lymph node metastases $(p=0.011)$. Finally, for patients with vascular invasion of the tumour a significantly higher prevalence rate of anti-E7 6-35 was found in comparison with patients without vascular invasion $(p=0.04)$. In the analysis of clinicopathological data on antiE7\6-35 using logistic regression analysis we considered stage, lesion size, differentiation grade, and presence or absence of lymph node metastases. The analysis revealed a significant independent effect of both a lesion size $\geq 4 \mathrm{~cm}$ and nodal spread on anti-E7\6-35 positivity $\left(\chi^{2}=17 \cdot 64 ; \quad \mathrm{df}=2 ; \quad \mathrm{p}=0.0001 ;\right.$ sensitivity $33.3 \%$; specificity $90.2 \%$ ).

We further analysed the predictive value of four pretreatment indices (stage, lesion size, differentiation grade, and anti-E7 $\backslash 6-35$ positivity) for the presence of lymph node metastases. Logistic regression analysis showed a statistically significant effect of both anti-E7 $\backslash$ 6-35 positivity and lesion size before treatment on nodal spread $\left(\chi^{2}=13.01 ; \mathrm{df}=2 ; \mathrm{p}=0.0015\right.$; sensitivity $28 \cdot 2 \%$; specificity $90 \cdot 5 \%$ ).

ANTI-E7 16 -35 ANTIBODIES AND PROGNOSIS

When the presence of antibodies against E7 6-35 in pretreatment sera was correlated with prognosis, a significantly higher prevalence rate of antibodies against E7 $76-35$ was found in patients who ultimately died of disease (32/ $105,30.5 \%)$ in comparison with patients who showed no evidence of disease at the closing date of the study $(35 / 243,14 \cdot 4 \%, p=0 \cdot 0008)$.

We performed an analysis of data of 144 patients with stage IB or IIA. Using the Cox regression model we considered three pretreatment prognostic factors (age, lesion size, and histological grade) which can be determined before surgery, and E7 $\backslash 6-35$ positivity (since the lymph node status cannot be determined before surgery, these data were not included). The analysis revealed independent effects of anti-E7\6-35 positivity $(p=0.01)$ and-to a lesser extent-lesion size $(p=0.07)$ on survival. Survival curves in relation to antiE7 $\backslash 6-35$ positivity are shown in the figure. Statistical analysis of the survival curves (log
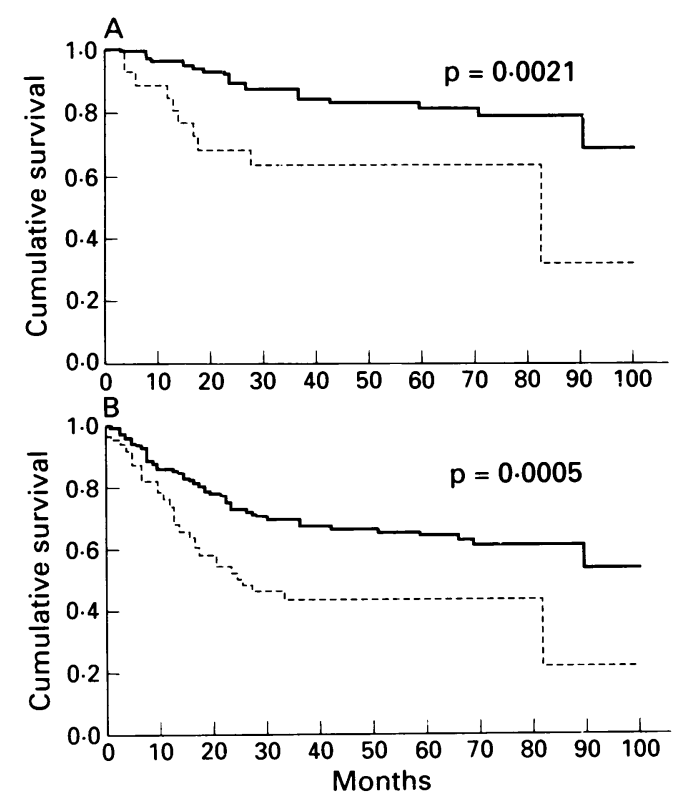

Cumulative survival in anti-E $\backslash \backslash 6-35$ negative and positive cervical carcinoma patients. (A) FIGO stage IB/ IIA patients; (B) all FIGO stages. Continuous line $=$ anti-E\ 6-35 negative patients; interrupted line $=$ anti-E 6-35 positive patients.

rank test) showed that seropositive stage IB and IIA patients have a significantly shorter life expectancy than seronegative patients $(p=$ 0.0021 ). A similar difference in survival was found for all stages taken together $(p=0.0005)$.

\section{Discussion}

Up to now, no data have been available on the correlation between antibodies against HPV$16 \mathrm{E} 7$ in pretreatment sera from patients with cervical carcinoma and tumour or patient related variables.

An overall prevalence rate of antibodies against peptide E7 $\backslash 6-35$ of $17 \cdot 7 \%$ was found in patients with cervical cancer, which was significantly higher than in the control group or in patients with cervical intraepithelial neoplasia. Similar results have been reported earlier. Jochmus-Kudielka et $a l^{6}{ }^{6}$ using a bacterial HPV-16 E7 fusion protein, reported a prevalence rate of $20.5 \%$ in cervical cancer patients. Krchnak et al, ${ }^{7}$ using a synthetic peptide comprising amino acids 11 to 30, obtained a prevalence rate of $24 \%$. Müller et $a l,{ }^{9}$ using a peptide identical to peptide E7\6-35 in this study, found a prevalence rate of $37 \%$ in HPV16 DNA positive cervical cancer patients. Unfortunately, no data concerning the presence of HPV DNA in the tumour tissues were available from the cervical cancer patients in this study.

When cervical cancer patients were classified according to stage, a significantly different prevalence rate of antibodies against E7 $\backslash 6-35$ was observed between the four FIGO stages, the highest prevalence being observed in stage IV patients. Further analysis of the data on antiE7 positivity in relation to clinicopathological indices revealed a significant correlation between the presence of antibodies against HPV16 E7 $\backslash 6-35$ in pretreatment sera and a larger lesion size, dedifferentiation, and lymph node 
metastasis. After logistic regression analysis only lesion size and the node status showed an independent effect on anti-E7 positivity. This latter finding is in agreement with the data from Onda $e t a l,{ }^{17}$ which show that lymph node and distant metastases are more frequent in antibody positive patients than in antibody negative patients.

Anti-E7 positivity was also shown to provide prognostic information. When the prognostic value of anti-E7 positivity was analysed in addition to three prognostic indices which can be determined before therapy (age, lesion size, and histological grade), only anti-E7 positivity correlated with poor survival. The prognostic value of pretreatment anti-E7 positivity may be explained by the association of anti-E7 positivity and tumour spread to the regional lymph nodes, which is a strong indicator of poor prognosis.

In conclusion, the results of this study show that the presence of antibodies against E7\6-35 in pretreatment sera from patients with cervical carcinoma correlates with the size of the lesion, lymph node involvement, and a worse prognosis. However, since anti-E7\6-35 antibodies are only detected in a minority of patients with cervical cancer, the clinical value of detection of antibodies against E7 $\backslash 6-35$ as a tumour or progression marker is low. The use of E7 antigens resembling the native state, possibly in combination with E6 antigens, might lead to assays with greater sensitivity and specificity. ${ }^{111819}$ The results obtained in this study warrant further studies on the value of antibodies against E7 as tumour or progression markers using E7 antigens resembling the native state.

The authors gratefully acknowledge the excellent technical assistance of Barbara Kremers, Andrew Beevers, and Corine Vermeulen. We would also like to thank Klaske ten Hoor and Mindert Krans for collection of serum samples and data management. This study was partly financed by the Dutch Prevention Fund, grant No 1502.

1 Pfister H. Biology and biochemistry of papillomaviruses. Rev Physiol Biochem Pharmacol 1984;99:112-81.

2 Pfister H. Human papillomaviruses and genital cancer. $A d v$ Cancer Res 1987;48:113-47.
3 Cullen AP, Reid R, Campion M, Lorincz AT. Analysis of the physical state of different human papillomavirus DNAs in intra-epithelial and invasive cervical neoplasm. $\mathcal{f}$ Virol in intra-epithelial

4 Yee C, Krishnan-Hewlett I, Baker CC, Schlegel R, Howley PM. Presence and expression of human papillomavirus sequences in human cervical carcinoma cell lines. $\mathrm{Am} \mathfrak{f}$ Pathol 1985;119:361-6.

5 Van den Brule AJ, Cromme FV, Snijders PJ, Smit L, Oudejans CB, Baak JP, et al. Nonradioactive RNA in situ hybridization detection of human papillomavirus 16-E7 transcripts in squamous cell carcinomas of the uterine cervix using confocal laser scan microscopy. Am $\mathcal{f}$ Pathol 1991;139:1037-45.

6 Jochmus-Kudielka I, Schneider A, Braun R, Kimmig R, Koldovsky U, Schneweis KE, et al. Antibodies against the human papillomavirus type 16 early proteins in human human papilomavirus type 16 early proteins in human sera: correlation of anti-E7 reactivity with

7 Krchnak V, Vagner J, Suchankova A, Krcmar M, Ritterova L, Vonka V. Synthetic peptides derived from E7 region of human papillomavirus type 16 used as antigens in ELISA f Gen Virol 1990;71:2719-24.

8 Mann VM, Loo de Lao S, Brenes M, Brinton LA, Rawls $\mathrm{JA}$, Green $\mathrm{M}$, et al. Occurrence of IgA and IgG antibodies to select peptides representing human papillomavirus typ 16 among cervical cancer cases and controls. Cancer Res 1990;50:7815-9.

9 Müller M, Viscidi RP, Sun Y, Guerrero E, Hill PM, Shah F, et al. Antibodies to HPV-16 E6 and E7 proteins as markers for HPV-16-associated invasive cervical cancer. Virology 1992;187:508-14.

10 Dillner J. Mapping of linear epitopes of the human papillomavirus type 16: the E1, E2, E4, E5, E6 and E7 open lomavirus type 16: the E1, E2, E4, E5, E6 a

11 Müller M, Gausepohl H, Martinoff G de, Frank R, Brasseur $\mathrm{R}$, Gissmann L. Identification of seroreactive regions of the human papillomavirus type 16 proteins $\mathrm{E} 4, \mathrm{E} 6, \mathrm{E} 7$ and L1. $\mathcal{f}$ Gen Virol 1990;71:2709-17.

12 Tindle RW, Smith JA, Geysen HM, Selvey LA, Frazer IH. Identification of B epitopes in human papillomavirus type 16 E7 open reading frame protein. $f$ Gen Virol 1990;71: 1347-54.

13 Comerford SA, McCance DJ, Dougan G, Tite JP. Identification of T- and B-cell epitopes of the E7 protein of tification of T- and B-cell epitopes of the E7 protein of

14 Ferenczy A, Winkler B. Carcinoma and metastatic tumours of the cervix. In: RJ Kurman, ed. Blaustein's Pathology of of the cervix. In: RJ Kurman, ed. Blaustein's Pathology of the female

15 Duk JM, Aalders JG, Fleuren GJ, Krans M, de Bruijn HWA. Tumour markers CA 125, squamous cell carcinoma antigen, and carcinoembryonic antigen in patients with adenocarcinoma of the uterine cervix. Obstet Gynaecol 1989;73:661-8.

16 Merrifield RB. Solid phase synthesis. I. The synthesis of a tetrapeptide. F Am Chem Soc 1963;85:2149-54.

17 Onda T, Kanda T, Zanma S, Yasugi T, Watanabe S, Kawana $T$, et al. Association of the antibodies against human papillomavirus 16E4 and E7 proteins with cervical can papillomavirus 16E4 and E7 proteins with cervical cancer positive for huma

18 Stacey SN, Ghosh A, Bartholomew JS, Tindle RW, Stern PL, Mackett M, et al. Expression of human papillomavirus type 16 E7 protein by recombinant baculovirus and use for the detection of E7 antibodies in sera from cervical carcinoma patients. $\mathcal{f}$ Med Virol 1993;40:14-21.

19 Viscidi RP, Sun Y, Tsuzaki B, Bosch FX, Munoz N, Shah KV. Serologic response in human papillomavirus-associated invasive cervical cancer. Int $\mathcal{f}$ Cancer 1993;55:780-4. 